\title{
Arrival of the invasive amphipod Grandidierella japonica to the Mediterranean Sea
}

\author{
Agnese Marchini", Jasmine Ferrario and Emanuele Nasi
}

\begin{abstract}
Background: In the marine environment, shipping is globally acknowledged as the major vector of introduction of organisms outside their native range. We surveyed harbours and marinas in the Western Mediterranean Sea for occurrence of non-indigenous species.

Results: More than 200 specimens of the Japanese amphipod Grandidierella japonica were collected in 2013 from the docks of the marina of Viareggio (Tuscany, Tyrrhenian Sea). This is the first record of this species for the Mediterranean Sea.

Conclusions: G. japonica was previously introduced elsewhere by oyster trade and shipping; in the case of Viareggio, where no aquaculture facilities or international shipping occur, recreational boating is the only likely vector of introduction. In Europe, G. japonica is currently confined by a few localities, mainly estuaries, enclosed bays and brackish water areas, but its successful history of invasion in the Pacific coasts of North America suggests that a further spread can be expected in the Mediterranean Sea as well.
\end{abstract}

Keywords: Aorid amphipod, Crustacean, Introduced species, Fouling, Shipping, Recreational boating, Mediterranean Sea, Marina, Brackish water, Ficopomatus enigmaticus

\section{Background}

While analysing crustaceans collected in July 2013 in a marina in Tuscany (Italy), we noticed an unusual aorid amphipod, with a male gnathopod 1 presenting 18-20 transverse fine ridges on the anterior edge of carpus. The enlarged basis of male gnathopod 1 and the uniramous uropod 3 lead to the identification of the genus Grandidierella, which is not native to the Mediterranean Sea (Lo Brutto et al. 2016). Although Grandidierella is a rather speciose genus, with 43 currently accepted species (Lowry 2016), only 5 of them have the "stridulating ridges" (Stephensen 1938) on male gnathopod 1 carpus and, within them, only one has 3 teeth (one main tooth and two accessory teeth) at the posterodistal corner of the carpus: Grandidierella japonica Stephensen 1938.

This species was originally described from Japan. It is now widely distributed in the entire Pacific Ocean, also

\footnotetext{
* Correspondence: agnese.marchini@unipv.it Department of Earth and Environmental Sciences, University of Pavia, Via S. Epifanio 14, 27100 Pavia, Italy
}

(C) 2016 Marchini et al. Open Access This article is distributed under the terms of the Creative Commons Attribution 4.0 International License (http://creativecommons.org/licenses/by/4.0/), which permits unrestricted use, distribution, and reproduction in any medium, provided you give appropriate credit to the original author(s) and the source, provide a link to the Creative Commons license, and indicate if changes were made. The Creative Commons Public Domain Dedication waiver (http://creativecommons.org/publicdomain/zero/1.0/) applies to the data made available in this article, unless otherwise stated.

\section{Results}

Systematics

Order AMPHIPODA Latreille, 1816

Suborder SENTICAUDATA Lowry \& Myers, 2013

Family AORIDAE Stebbing, 1899

Genus Grandidierella Coutière, 1904 
Grandidierella japonica Stephensen 1938

(Fig. 2)

\section{Material examined}

Areas A, B and C (marina of Viareggio, Italy; Fig. 1b; Table 1): Grandidierella japonica (Fig. 2), 245 specimens, maximum size $7.5 \mathrm{~mm}$ (ovigerous female) and $6.2 \mathrm{~mm}$ (male).

\section{Diagnosis}

The collected specimens correspond to the original description of G. japonica provided by Stephensen (1938). Diagnostic characters are: uniramous uropod 3 (Fig. 2), a short medio-ventral spine on peraeon segment 1 , ovoidal basis of male gnathopod 1 (Fig. 3a, b), two accessory teeth on gnathopod 1 carpus (Fig. $3 \mathrm{~b}$ ), presence of stridulating ridges on the male carpus anterior margin (Fig. 3a, b).

\section{Comparison}

Descriptions of G. japonica were provided by several authors after records from various localities, sometimes highlighting variations, mainly related to male gnathopod 1. The short medio-ventral spine on peraeon segment 1, described by Stephensen (1938) and clearly visible in our specimens, was also drawn by Chapman and Dorman (1975), Ariyama (1996) and Smith et al. (1999), but was absent in Nagata (1960) specimens. Nagata (1960) also noticed that the basis of male gnathopod 1 is «somewhat oblong oval rather than that in Stephensen's specimens». The basis of male gnathopod 1 drawn in Stephensen (1938), Chapman and Dorman (1975), and photographed by Berggren (2015), is ovoidal, as well as in Viareggio specimens. Conversely, male gnathopods 1 drawn by Nagata (1965), Hirayama (1984) and Smith et al. (1999) are closer to Nagata (1960) description.

The two accessory teeth on gnathopod 1 carpus were indicated as a prominent and diagnostic character (Stephensen 1938; Chapman and Dorman 1975; Ariyama 1996). However, Myers (1981) described rather small male specimens from Australia lacking one of them. In our samples, the median tooth on the inner surface of carpus near posterior margin was always visible, but the small accessory tooth on inner surface of anterior side of the strong tooth was evident only in larger males (Fig. 3b). Also Morino and Dai (1990) observed that a small male had only a rudimentary process, whilst the accessory tooth was visible in a large male. Therefore, it is possible that this character varies with maturity. Number of stridulating ridges on the male carpus anterior

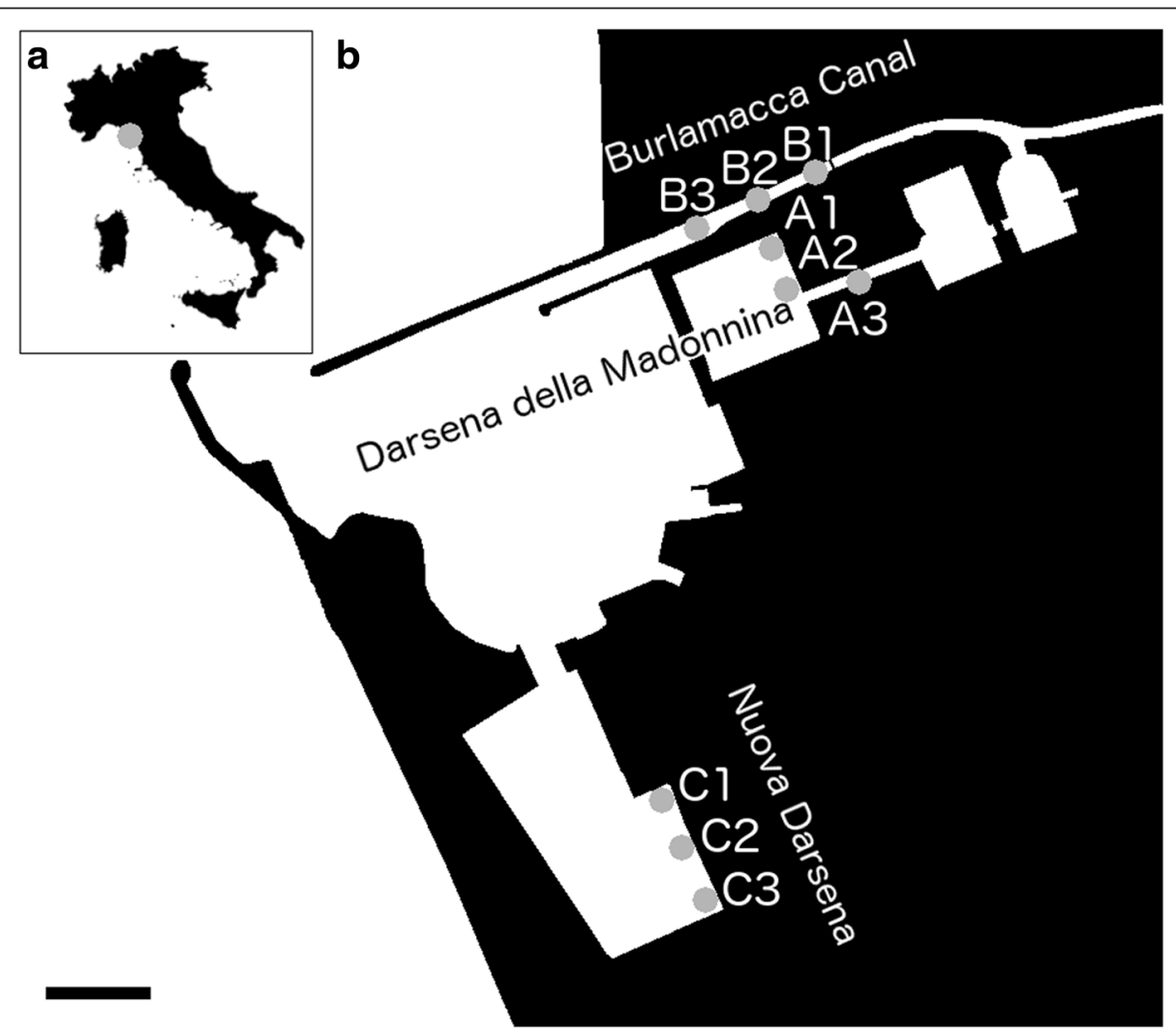

Fig. 1 Study area: (a) Location of Viareggio (Tuscany, Italy); (b) map of the marina, indicating the three sampling areas: A- Darsena della Madonnina, B- Burlamacca Canal, C- Nuova Darsena. Scale bar: 200 m 
Table 1 GPS coordinates, temperature and salinity values recorded in the marina of Viareggio

\begin{tabular}{lllll}
\hline Replicates & Longitude $(\mathrm{E})$ & Latitude $(\mathrm{N})$ & Temperature $\left({ }^{\circ} \mathrm{C}\right)$ & Salinity (PSU) \\
\hline A1 & 10.24355 & 43.86370 & & \\
A2 & 10.24348 & 43.86375 & 25 & 20.9 \\
A3 & 10.2439 & 43.86337 & & \\
& & & & \\
B1 & 10.24389 & 43.86481 & 15.8 \\
B2 & 10.24332 & 43.86423 & 26 & \\
B3 & 10.24206 & 43.86396 & & \\
C1 & 10.24173 & 43.85706 & & 34.2 \\
C2 & 10.24165 & 43.85663 & 25 & \\
C3 & 10.24215 & 43.85587 & & \\
\hline
\end{tabular}

margin is also variable, from 18-20 ridges in Stephensen (1938), to 30 or more ridges counted from the drawings in Chapman and Dorman (1975) and Hirayama (1984), from a photo in Lavesque et al. (2014) and in our specimens (Fig. 3a, b), up to 40 ridges in Ariyama (1996).

Finally, populations described from different localities present a rather wide size range, from 4-5 mm (Myers 1981; Hirayama 1984; Ashelby 2006) to 9-12 mm (Stephensen 1938; Nagata 1960; 1965; Ariyama 1996), up to $22 \mathrm{~mm}$ (Chapman and Dorman 1975). The maximum observed sizes of our specimens were $7.5 \mathrm{~mm}$ (ovigerous female), and $6.2 \mathrm{~mm}$ (male).

\section{Remarks}

Specimens of G. japonica were especially abundant in the area $\mathrm{A}$ and $\mathrm{B}$, where it was present in all the replicates, while just a single replicate was recorded in the

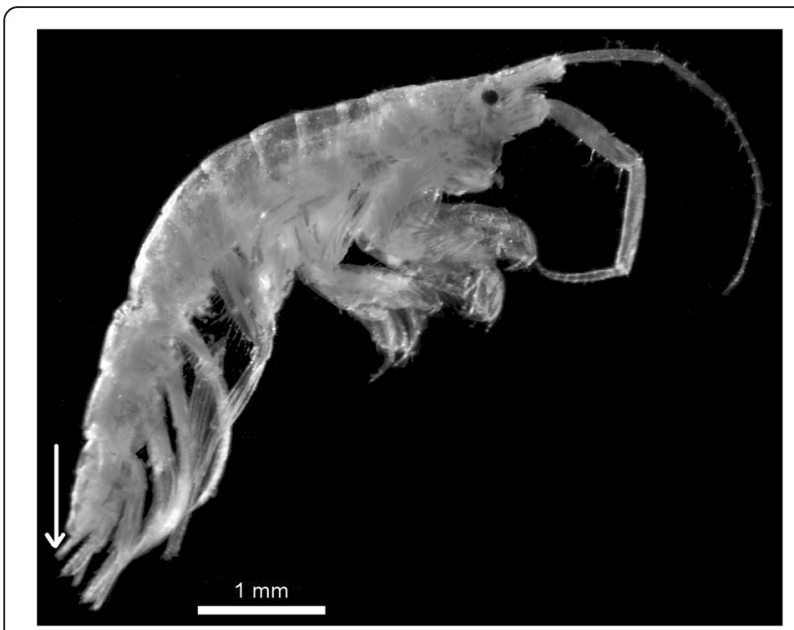

Fig. 2 Grandidierella japonica Stephensen 1938 from Viareggio (Italy, Tyrrhenian Sea): male specimen $(5.4 \mathrm{~mm}$ ). The arrow indicates uniramous uropod 3, a character of the genus Grandidierella which differs from other Mediterranean aorid amphipods area C. Among the total specimens collected, 74 specimens (out of which 21 males, 38 ovigerous females and 15 juveniles) were recorded in area A; 170 specimens (out of which 40 males, 96 ovigerous females and 34 juveniles) in area B; and 1 ovigerous female in area $C$.

Salinity and temperature recorded in the three areas are shown in Table 1; areas A and B exhibited brackish water conditions, due to the freshwater inflow of an artificial canal, whereas salinity in area $\mathrm{C}$ approached fully marine conditions.

The benthic community characterising areas A and B were dominated by the non-indigenous polychaete Ficopomatus enigmaticus (Fauvel 1923), which formed conspicuous reefs along the docks. Flourishing colonies of another non-indigenous invertebrate, the bryozoan Amathia verticillata (Delle Chiaje 1822), characterised area C.

\section{Discussion}

\section{Pathway of introduction}

Previous records of Grandidierella japonica outside its native range have been explained from importation with the Japanese oyster Crassostrea gigas (Thunberg 1793; Chapman and Dorman 1975; Jourde et al. 2013; Lavesque et al. 2014), transport in ballast water, or from fouling associated with international shipping (Carlton and Eldredge 2009). The transport due to small recreational boats that travel between estuaries was defined "unlikely" by Pilgrim et al. (2013).

International shipping and oyster farming, however, do not take place in the marina of Viareggio, which is devoted to pleasure and fishing boats. Recreational boating has recently been regarded as an often overlooked vector of introduction and secondary spread of marine nonindigenous species (Clarke Murray et al. 2011; Davidson et al. 2010; Ros et al. 2013; Zabin et al. 2014). Sessile species (macroalgae, serpulids, barnacles, tunicates, bryozoans, and others) that attach on the hulls of sailing boats or motorboats can provide refuge and substratum for associated motile invertebrates, such as nudibranchs, peracarid crustaceans, pycnogonids (Brine et al. 2013; Mineur et al. 2012; Marchini et al. 2015a), thus facilitating their transport and accelerating their spread.

Several amphipod and isopod species are likely to be transported in the fouling by recreational boats, e.g. Caprella mutica Schurin 1935, Caprella scaura Templeton 1836, Jassa marmorata Holmes 1905, Paracaprella pusilla Mayer 1890, Paranthura japonica Richardson 1909, Paracerceis sculpta (Holmes 1904), as suggested by their frequent occurrence in marinas (Frey et al. 2009; Minchin et al. 2012; Ros et al. 2013; Ashton et al. 2014; McCollin and Brown 2014; Zabin et al. 2014; Marchini et al. 2015a; Ramalhosa and Canning-Clode 2015). G. japonica therefore adds to the list of peracarid crustaceans being spread by pleasure boats. 

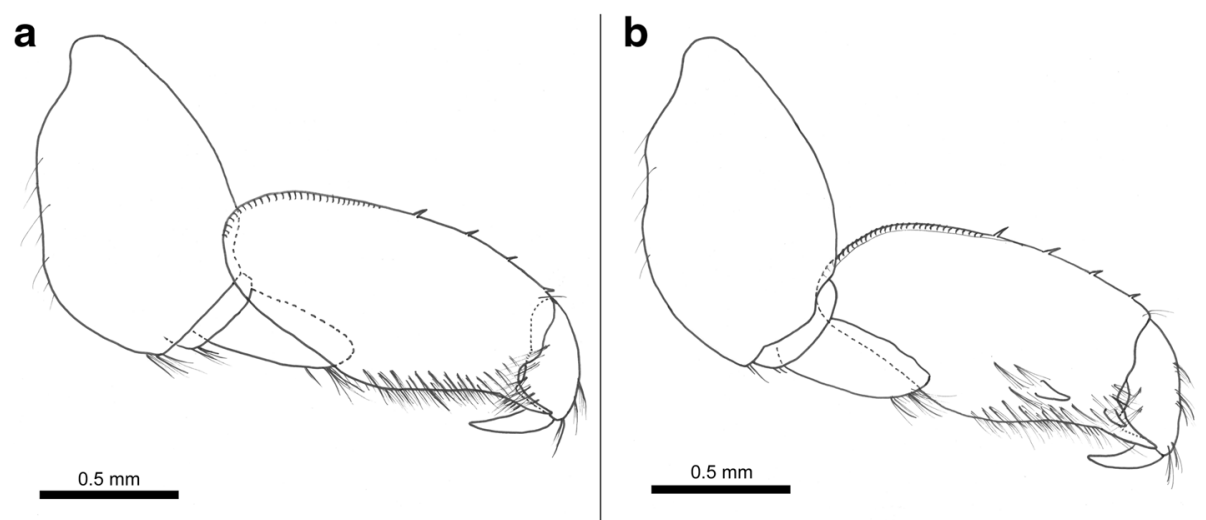

Fig. 3 Grandidierella japonica Stephensen 1938 from Viareggio (Italy, Tyrrhenian Sea). a Right male gnathopod 1, outer side; b left male gnathopod 1, inner side

While the vector of introduction is clarified, the source origin of the G. japonica population observed in Viareggio is still unknown. Whether a direct introduction event from the native region, or a secondary introduction from another European (or even Mediterranean) site of introduction, any hypotheses cannot be rejected or retained with certainty.

The analysis of samples collected in 2013-2015 during surveys of several French and Italian lagoon, harbour and marina sites of the Western Mediterranean Sea (localities: La Grande Motte, Genoa, Santa Margherita Ligure, La Spezia, Lerici, Leghorn, Viareggio, Orbetello, Olbia, Porto Torres, Castelsardo, Porto Rotondo; Ferrario et al., in preparation) allowed us to exclude the occurrence of G. japonica in localities other than Viareggio. A survey conducted by our research group in 2012 in the "sink and source" area of introductions in Italy, i.e. the Lagoon of Venice (Marchini et al. 2015b) was also negative as for the presence of G. japonica.

Salinity preference might partially explain this result: Viareggio was the only marina we examined that displayed brackish conditions, and within Viareggio, G. japonica only occurred in the most brackish areas (A and B), being substituted by another aorid amphipod, Microdeutopus gryllotalpa Costa 1853, in area C where salinity values were higher.

Another relevant characteristic of areas A and B in Viareggio marina is the coverage of the dock walls by dense reefs of the tubeworm Ficopomatus enigmaticus, a species not observed elsewhere in our survey. F. enigmaticus is an ecosystem engineer that creates novel, large, three-dimensional structures on the hulls of boats as well as in marinas, thus creating a suitable habitat for associated non-indigenous invertebrates which are favoured in their transfer and settlement (Heiman et al. 2008; Mineur et al. 2012; Zabin et al. 2014). An association between $F$. enigmaticus and $G$. japonica has already been observed in California (Elkhorn Slough estuary; Wasson et al. 2001).

At present, Viareggio marina therefore represents the first and only Mediterranean locality where G. japonica might be established. However, its successful history of invasion in North America (46 invaded estuaries along the Pacific coast; Pilgrim et al. 2013) suggests that a further spread can be expected in the future, particularly in brackish water areas such as lagoons and estuaries colonised by F. enigmaticus (which is known from 15 lagoons in Italy; Basset et al. 2006).

\section{Distribution and ecology}

The current distribution of G. japonica indicates it is a eurytopic species: in the Pacific Ocean, it ranges from Russia (Kudrjaschov and Tzvetkova 1975) to Canada (Pilgrim et al. 2013), California (Chapman and Dorman 1975; Greenstein and Tiefenthaler 1997), Australia (Myers 1981) and Hawaii (Muir 1997). Another record from Mexico (Okolodkov et al. 2007), is awaiting confirmation (Rodríguez-Almaraz and García-Madrigal 2014). In Europe, G. japonica ranges from the Swedish coasts (Berggren 2015) to Britain (Ashelby 2006), the Celtic-Biscay Shelf (Smith et al. 1999; Jourde et al. 2013; Lavesque et al. 2014) and the Mediterranean Sea (present study). It is able to colonise a large variety of habitats such as muddy and sandy bottoms in the lower intertidal zone (Ariyama 1996; Chapman and Dorman 1975; Smith et al. 1999), seagrass beds (Zostera spp., Ruppia spp.; Nagata 1960; Chapman and Dorman 1975; Lavesque et al. 2014), oyster beds (Chapman and Dorman 1975), F. enigmaticus reefs (Wasson et al. 2001; present study), on different algal species, on experimental artificial substrates (Aikins and Kikuchi 2001), brackish waters, estuaries and lagoons (Stephensen 1938; Ashelby 2006; Lavesque et al. 2014), harbours and marinas (Chapman and Dorman 1975; Muir 1997; present 
study), and near sewage treatment plants (Chapman and Dorman 1975). It was one of the animals able to tolerate the highest variations in salinity during experiments of ballast tanks treatment with concentrated sodium chloride brine solutions: G. japonica had $65 \%$ survivorship after $48 \mathrm{~h}$ at $45 \mathrm{ppt}$ sodium chloride solution (Santagata et al. 2009). Such widespreadness and generalism lead Pilgrim et al. (2013) to suspect the existence of cryptic diversity and a complex introduction history of G. japonica. They conducted molecular analyses on populations of G. japonica from several estuaries along the Pacific North American coasts and discovered the cooccurrence of two different lineages: a clade A, that has spread from San Francisco Bay northward, and a clade B, only found from San Francisco Bay southward. This result raises questions about the taxonomic identity of the two evolutionarily divergent clades introduced to North America. Unfortunately, Pilgrim et al. (2013) did not provide a taxonomic description of the two clades, suggesting that no clear morphological differences were observable.

However, a few morphological differences appear in the various descriptions of G. japonica (see the Results section). Such minute but constant morphological differences occurring within putative "cosmopolitan" amphipods have revealed the existence of species complexes (e.g. Krapp-Schickel and De Broyer 2014; Krapp-Schickel 2015). As Pilgrim et al. (2013) pointed out, a taxonomic revision based on comparative material and combined with ecological observations and genetic analysis of $G$. japonica populations are necessary to verify the existence of constant morphological differences between clades, the relevance of the observed variability in ecological tolerance, and to have more insights on the nature, source and pathways of this invasion.

\section{Conclusions}

The recent appearance of Grandiderella japonica in the Mediterranean Sea confirms the ability of this amphipod to spread and colonise a large range of coastal habitats, therefore a further spread can be expected in the Mediterranean Sea in the next future.

\section{Methods}

The marina of Viareggio is located in the north of Tuscany (Tyrrhenian Sea, Italy; Fig. 1a). It hosts six docks, for a total number of 2000 berths. We collected benthic invertebrates from three distinct areas in the marina (Fig. 1b): the dock called "Darsena della Madonnina", a mooring area for resident leisure craft (area A); the canal harbour called "Burlamacca", a mooring area for transient leisure craft (area B); the dock called "Nuova Darsena", a fishing boats transit area (area C). Three replicates were collected from each area. The sampling was carried out on June 27, 2013 by scraping the artificial hard substrate, i.e. the main dock walls, with a hand-held rigid net $(25 \times 20 \mathrm{~cm})$, over an area of approximately $0.23 \mathrm{~m}^{2}$. Samples were subsequently fixed in formalin $(5 \%)$ and sorted under a stereoscopic microscope. Specimens of Grandidierella japonica were separated from the community, examined under a dissecting microscope, and photographed with an AXIO CAM ERc5s camera, using the Software ZEISS- AXIO VISION 4 for total length measures.

\section{Acknowledgments}

The authors gratefully thank Alan Myers for suggestions and support in the initial phase of identification process, and one anonymous reviewer for comments which improved the paper.

\section{Funding \\ JF was supported by a PhD grant from the University of Pavia.}

\section{Availability of data and materials}

Specimens of Grandidierella japonica are deposited in the Natural History Museum of the University of Pavia, Italy (code: MSNPV-2016/05). The record has also been registered in the online information system on Aquatic NonIndigenous and Cryptogenic Species AquaNIS (AquaNIS Editorial Board, 2015. Information system on Aquatic Non-Indigenous and Cryptogenic Species. World Wide Web electronic publication. www.corpi.ku.t/databases/aquanis. Version 2.36+. Accessed 2016-05-12).

\section{Authors' contributions}

AM conceived the study, partecipated in the identification of Grandidierella japonica and wrote the manuscript. JF planned and carried out field activities and contributed to writing, drawings and figures. EN participated in fieldwork activities, counted specimens, contributed to taxonomic identification and drawings. All authors read and approved the final manuscript.

\section{Authors' information}

AM and JF are postdoc researchers at University of Pavia; EN is an undergraduate working on amphipods in marinas.

\section{Competing interests}

The authors declare that they have no competing interests.

Received: 12 May 2016 Accepted: 3 June 2016

Published online: 18 July 2016

\section{References}

Aikins S, Kikuchi E. Studies on habitat selection by amphipods using artificial substrates within an estuarine environment. Hydrobiologia. 2001:457(1-3):77-86.

Ariyama H. Four Species of the Genus Grandidierella (Crustacea: Amphipoda: Aoridae) from Osaka Bay and the Northern Part of the Kii Channel, Central Japan. Publ Seto Mar Biol Lab. 1996:37(1-2):167-91.

Ashelby C. Record of the introduced amphipod Grandidierella japonica Stephensen 1938 (Crustacea: Amphipoda: Gammaridea: Aoridae) from the Orwell estuary, Suffolk. Trans Suffolk Nat Soc. 2006;42:48-54.

Ashton G, Davidson I, Ruiz G. Transient small boats as a long-distance coastal vector for dispersal of biofouling organisms. Estuar Coasts. 2014;37(6):1572-81.

Basset A, Galuppo N, Sabetta L. Environmental heterogeneity and benthic macroinvertebrate guilds in italian lagoons. Transit Water Bull. 2006;1:48-63.

Berggren M. Nya kräftdjur påträffade i Sverige - Grandidierella japonica och Rhithropanopeus harrisii. Fauna \& Flora. 2015;110(1):20-3.

Brine O, Hunt L, Costello MJ. Marine biofouling on recreational boats on swing moorings and berths. Management of Biological Invasions. 2013:4(4):327-41 
Carlton JT, Eldredge LG. Marine bioinvasions of Hawai'i: the introduced and cryptogenic marine and estuarine animals and plants of the Hawaiian archipelago, Bishop Museum Bulletin in Cultural and Environmental Studies. Honolulu: Bishop Museum Press; 2009. p. 202.

Chapman JW, Dorman JA. Diagnosis, systematics, and notes on Grandidierella japonica (Amphipoda: Gammaridea) and its introduction to the Pacific coast of the United States. Bull South Calif Acad Sci. 1975;74:104-8.

Clarke Murray C, Pakhomov EA, Therriault TW. Recreational boating: a large unregulated vector transporting marine invasive species. Divers Distrib. 2011; 17(6):1161-72.

Costa A. Relazione sulla memoria del Dottore Achille Costa, di ricerche su crostacei anfipodi del regno di Napoli. Rendiconto della Società Reale Borbonica, Accademia delle Scienze. 1853;2:166-78.

Coutière H. Sur un type nouveau d'amphipode Grandidierella mahafalensis, provenant de Madagascar. Bulletin de la Association Philomatique. 1904;6:166-174.

Davidson IC, Zabin CJ, Chang AL, Brown CW, Sytsma MD, Ruiz GM. Recreational boats as potential vectors of marine organisms at an invasion hotspot. Aquat Biol. 2010;11(2):179-91.

Delle Chiaje S. Memorie sulla Storia e Notomia degli Animali senza Vertebre del Regno di Napoli. Naples: Fratelli Fernandes; 1822. p. 184.

Fauvel P. Un nouveau serpulien d'eau saumatre Mercierella n.g., enigmatica n.sp. Bulletin de la Société Zoologique de France. 1923;47:424-30.

Frey MA, Gartner HN, Clarke MC, Therriault TW. First confirmed records of the non-native amphipod Caprella mutica (Schurin 1935) along the coast of British Columbia, Canada, and the potential for secondary spread via hull fouling. Aquat Invasions. 2009;4:495-9.

Greenstein DJ, Tiefenthaler LL. Reproduction and population dynamics of a population of Grandidierella japonica (Stephensen) (Crustacea: Amphipoda) in upper Newport Bay, California. Bull South California Acad Sci. 1997;96(1):34-42.

Heiman KW, Vidargas N, Micheli F. Non-native habitat as home for non-native species: comparison of communities associated with invasive tubeworm and native oyster reefs. Aquat Biol. 2008;2(1):47-56.

Hirayama A. Taxonomic studies on the shallow water gammaridean amphipoda of West Kyushu, Japan -II. Corophiidae. Publ Seto Mar Biol Lab. 1984;29(1-3):1-92.

Holmes SJ. Remarks on the sexes of Sphaeromids: with a description of a new species of Dynamene. Proc California Acad Sci, 3rd Ser, Zool. 1904; 3(2):295-306

Holmes SJ. The Amphipoda of Southern New England. Bull US Bur Fish. 1905;24: 457-529.

Jourde J, Sauriau PG, Guenneteau S, Caillot E. First record of Grandidierella japonica Stephensen, 1938 (Amphipoda: Aoridae) from mainland Europe. Biolnvasions Rec. 2013;2(1):51-5.

Kim YH, Eun Y, Lee KS. Amphipods (Gammaridea and Caprellidea). Fauna of Jindo Island in Korea. Korean J Syst Zool. 2005;12(5):1-11.

Krapp-Schickel T. Minute but constant morphological differences within members of Stenothoidae: the Stenothoe gallensis group with four new members, keys to Stenothoe worldwide, a new species of Parametopa and Sudanea n. gen. (Crustacea: Amphipoda). J Nat Hist. 2015;49(37-38):2309-77.

Krapp-Schickel T, De Broyer C. Revision of Leucothoe (Amphipoda, Crustacea) from the Southern Ocean: a cosmopolitanism concept is vanishing. Eur J Taxonomy. 2014;80:1-55.

Kudrjaschov VA, Tzvetkova NL. New and rare species of Amphipoda (Gammaridea) from the coastal waters of the South Sakhalin. Zoologicheski Zhurnal. 1975;54:1306-15.

Latreille PA. Amphipoda. In: Nouveau Dictionaire d'histoire naturelle, appliquée aux Arts, à l'Agriculture, à l'Économie rurale et domestique, à la Médecine, etc. Par une société de Naturalistes et d'Agriculteurs (2nd ed. Vol. 1). Paris: Deterville; 2002. p. 467-69.

Lavesque N, Gouillieux B, de Montaudouin X, Bachelet G, Bonifácio P, Simonet E. Premier signalement de l'espèce introduite Grandidierella japonica Stephensen, 1938 (Crustacea: Amphipoda: Aoridae) dans le bassin d'Arcachon. An aod-les cahiers naturalistes de l'Observatoire marin. 2014;3(1):11-9.

Lo Brutto S, laciofano D, Lubienevsky H, Galil BS. Grandidierella bonnieroides Stephensen, 1948 (Amphipoda, Aoridae) — first record of an established population in the Mediterranean Sea. Zootaxa. 2016;4092(4):518-28.

Lowry J. Grandidierella Coutière, 1904. In: Horton T., Lowry J., De Broyer C., Bellan-Santini D., Coleman C.O., Daneliya M., Dauvin J-C., Fišer C., Gasca R., Grabowski M., Guerra-García J.M., Hendrycks E., Holsinger J., Hughes L., Jazdzewski K., Just J., Kamaltynov R.M., Kim Y.-H., King R., Krapp-Schickel T.,
LeCroy S., Lörz A.-N., Senna A.R., Serejo C., Sket B., Tandberg A.H., Thomas J., Thurston M., Vader W., Väinölä R., Vonk R., White K., Zeidler W. (2016) World Amphipoda Database. 2016. World Wide Web electronic publication. http:// marinespecies.org/aphia.php?p=taxdetails\&id=205825 Accessed 2016-03-28.

Lowry JK, Myers AA. A Phylogeny and Classification of the Senticaudata subord. nov. Crustacea: Amphipoda). Zootaxa. 2013;3610(1):1-80.

Marchini A, Ferrario J, Minchin D. Marinas may act as hubs for the spread of the pseudoindigenous bryozoan Amathia verticillata (Delle Chiaje, 1822) and its associates. Sci Mar. 2015a;79(3):355-365.

Marchini A., Ferrario J., Sfriso A. and Occhipinti-Ambrogi A. Current status and trends of biological invasions in the Lagoon of Venice, a hotspot of marine NIS introductions in the Mediterranean Sea. Biol Invasions. 2015b;17(10):2943-2962.

Mayer P. Die Caprelliden des Golfes von Neapel und der angrenenden MeeresAbschnitte. Fauna und Flora des Golfes von Neapel. 1890;17:1-55.

McCollin T, Brown L. Native and non native marine biofouling species present on commercial vessels using Scottish dry docks and harbours. Manage Biol Invasions. 2014;5(2):85-96.

Minchin D, Lodola A, Occhipinti-Ambrogi A. The occurrence of Caprella scaura (Amphipoda: Caprellidae) in marinas in Lanzarote Island (Canary Archipelago, Macaronesia). Mar Biodiv Rec. 2012;5:e113.

Mineur F, Cook E, Minchin D, Bohn K, McLeod A, Maggs CA. Changing coasts: marine aliens and artificial structures. Oceanogr Mar Biol Annu Rev. 2012;50:189-234.

Morino H, Dai A. Three amphipod species (Crustacea) from East China. Publ Itako Hydrobiological Station. 1990;4:7-27.

Muir DG. New records of Peracarida Crustacea in Hawaii (Crustacea: Peracarida). Bishop Museum Occasional Publications. 1997;49:50-4.

Myers AA. Taxonomic studies on the genus Grandidierella Coutière (Crustacea, Amphipoda) III. Fijian, Australian and Saudi Arabian species. Bull Mus Natl Hist Nat, Paris. 1981;4(3):213-26.

Nagata K. Preliminary notes on benthic gammaridean amphipoda from the Zostera region of Mihara Bay, Seto Island Sea, Japan. Publ Seto Marine Biol Lab. 1960;8(1):163-82.

Nagata K. Studies on marine gammaridean amphipoda of the Seto Inland Sea. III. Publ Seto Mar Biol Lab. 1965;13(4):291-326.

Okolodkov YB, Bastida-Zavala R, Ibáñez AL, Chapman JW, Suárez-Morales E, Pedroche $F$, et al. Especies acuáticas no indígenas en México. Ciencia y Mar. 2007;11(32):29-67.

Pilgrim EM, Blum MJ, Reusser DA, Lee II H, Darling JA. Geographic range and structure of cryptic genetic diversity among Pacific North American populations of the non-native amphipod Grandidierella japonica. Biol Invasions. 2013;15(11):2415-28.

Ramalhosa P, Canning-Clode J. The invasive caprellid Caprella scaura Templeton, 1836 (Crustacea: Amphipoda: Caprellidae) arrives on Madeira Island, Portugal. Biolnvasions Rec. 2015;4:97-102.

Richardson H. Isopods collected in the northwest Pacific by the U.S. Bureau of Fisheries steamer "Albatross" in 1906. Proc US Natl Museum. 1909;37:75-129.

Rodríguez-Almaraz GA, García-Madrigal MS. Crustáceos exóticos invasores. Mendoza, R. \& P. Koleff (coords.). Especies acuáticas invasoras en México Comisión Nacional para el Conocimiento y Uso de la Biodiversidad, México. 2014;21:347-71.

Ros M, Vázquez-Luis M, Guerra-García JM. The role of marinas and recreational boating in the occurrence and distribution of exotic caprellids (Crustacea: Amphipoda) in the Western Mediterranean: Mallorca Island as a case study. J Sea Res. 2013;83:94-103.

Santagata S, Bacela K, Reid DF, Mclean KA, Cohen JS, Cordell JR, et al. Treatment for preventing the introduction of non indigenous species in the ballast tanks of ships declaring no ballast on board. Environ Toxicol Chem. 2009; 28(2):346-53.

Schurin A. Zur Fauna der Caprelliden der Bucht Peters der Grosse (Japanisches Meer). Zool Anz. 1935;112:198-203.

Smith P, Perrett J, Garwood P, Moore G. Two additions to the UK marine fauna: Desdemona ornata Banse, 1957 (Polychaeta, Sabellidae) and Grandidierella japonica Stephensen, 1938 (Amphipoda, Gammaridea). Newsletter of the Porcupine Marine Natural History Society. 1999;2:8-11.

Stebbing TRR. Revision of Amphipoda (continued). Annals and Magazine of Natural History. 1899;7(4):205-211.

Stephensen K. Grandidierella japonica n. sp., a new amphipod with stridulating (?) organs from brackish water in Japan. Annotationes Zoologicae Japonenses. 1938;17:179-84.

Templeton R. Descriptions of some undescribed exotic Crustacea. Trans R Entomological Soc London. 1836;1(3):185-98. 
Thunberg CP. Tekning och Beskrifning på en stor Ostronsort ifrån Japan. Kongliga Vetenskaps Academiens Nya Handlingar. 1793;14(4-6):140-2.

Wasson K, Zabin CJ, Bedinger L, Diaz MC, Pearse JS. Biological invasions of estuaries without international shipping: the importance of intraregional transport. Biol Conserv. 2001;102:143-53.

Zabin CJ, Ashton GV, Brown CW, Davidson IC, Sytsma MD, Ruiz GM. Small boats provide connectivity for nonindigenous marine species between a highly invaded international port and nearby coastal harbours. Manag Biol Invasions. 2014;5(2):97-112.

Submit your next manuscript to BioMed Central and we will help you at every step:

- We accept pre-submission inquiries

- Our selector tool helps you to find the most relevant journal

- We provide round the clock customer support

- Convenient online submission

- Thorough peer review

- Inclusion in PubMed and all major indexing services

- Maximum visibility for your research

Submit your manuscript at www.biomedcentral.com/submit
Biomed Central 